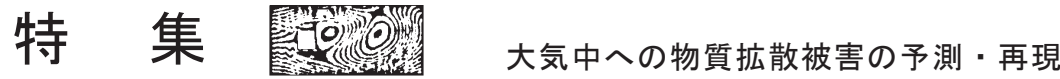

\section{数值流体解析を用いた降下火山灰のハザード評価技術の現状と課題 \\ Current Status and Future Prospects of Hazard Assessment Techniques of Volcanic Ash Fall using Computational Fluid Dynamics}

\author{
須藤 仁 ${ }^{* 1}$ 服部康男 ${ }^{* 2}$ 土志田 潔*3
}

Hitoshi SUTO, Yasuo HATTORI, Kiyoshi TOSHIDA

1.はじめに

日本列島は, 世界有数の火山発生地域に位置しており, 電力設備等の社会的重要構造物を立地・建設する際には, 近傍の火山活動の影響について，学際的に適切な評価を 行うことが求められる ${ }^{11,2)}$ 。火山現象の一つである降下火 山灰（以下，降灰）は，火山の爆発的な噴火により発生 した噴煙から火山灰粒子が落下し，降り積もる現象であ る。上空での移流・拡散を伴うため，火山噴火に伴い発 生する多様な現象の中でも，最も広範囲に影響を及ぼし うる。実際，地層（降下火山灰層）として残る降灰の発 生履歴は日本中で見出されており，全国どこでも被災す る可能性がある ${ }^{3)}$ 。

降灰の影響評価手法としては，過去の降圧履歴を明ら かにする文献調査，地形調査，地質調査等が基本となる が ${ }^{2}$, 降圧履歴で不足する情報を補う手段等として, 数值 流体解析の利用も進みつつある。火山灰の輸送に関わる 数值解析技術は，図 1 に示寸ように，火口からの上昇流 を主に対象とする噴煙柱モデルと，上昇した火砕物が大 気の影響を受けながら輸送される過程を主に対象とする 移流・拡散・沈降モデルに大別される。前者は，後者の
入力条件となる噴煙柱の高さや形状，粒径分布等を推定 するものであり，後者は，広域に降下した火山灰の量等 を直接推定するものである。そのため，降灰の影響評価 にはどちらも重要である。なお，降灰影響（リスク）に は，火山現象自体に起因する側面（ハザード）と，設備・ 機器等の工学的脆弱性で規定される側面とがあり，影響 の大きさはこれら 2 側面の乗算となる。

本報では，初めに，様々な降灰災害とその数值流体解 析との関わりについて述べる (2 章)。その上で，重要構 造物に対する降灰のハザード評価の視点から，著者らが 行った文献調査 ${ }^{4}$ に基づき, 火山灰の輸送に関わる数值流 体解析技術として，火山灰の移流・拡散・沈降評価（3 章) およひ噴煙柱評価 (4 章) の現状と今後取組みが望ま れる課題を整理する。なお，火口より噴出される火砕物 (火山砕屑物，高温状下で形成されるマグマの破片）に は，火山灰（粒子直径 $2 \mathrm{~mm}$ 以下）の他，より大きな粒 子直径のもの (火山礫，火山岩塊）が含まれるが，ここ では大気の影響を受けながら広範囲に輸送される火山灰 に話の焦点をあてる。

\footnotetext{
* 1 一般財団法人電力中央研究所 主任研究員

Research Engineer, Central Research Institute of Electric Power Industry *2 一般財団法人電力中央研究所 上席研究員

Senior Research Engineer, Central Research Institute of Electric Power Industry

* 3 一般財団法人電力中央研究所 主任研究員

Research Geologist, Central Research Institute of Electric Power Industry
} 


\section{2. 降灰災害と数值流体解析}

1 章で述べた通り, 降灰の発生履歴は地層として残り, 日本中で見出されている ${ }^{3)}$ 。日本付近の上空は西風が卓越 するため，降灰は火山の東方に伸びた形状で分布するも のが多い。白頭山（長白山）や穱陵島の噴火で発生した 降灰も国内に到達し堆積している。大規模な流体現象で ある噴煙・降灰を解明するために，数值流体解析は有用 な手段の一つとなる。

また，降灰による災害は広域的であり影響が長期化す るため, 事前対策不足や復旧の遅れによる副次的な影響 が特に大きい。これに対し，影響を事前に想定し対策を 講じることにより，迅速な復旧を図り風評被害等を軽減 することが可能である。関係諸機関が連携して対策を進 めるために, 数值流体解析に基づく影響評価が果たす役 割も大きい。

2 章では, 降灰災害とその数值流体解析との関わりにつ いて，火山噴火と降灰ハザードおよび，降灰災害と対策 の観点から，具体例を交えて述べる。

2. 1 火山噴火と降灰八ザード

噴火は大規模なものほど低頻度に発生する。国内最大 級の降灰は，噴出物量 100-1000 $\mathrm{km}^{3}$ 規模の噴火に伴い, 1 万年に 1,2 回発生しており, 全国的に厚さ $15 \mathrm{~cm}\left(150 \mathrm{~kg} / \mathrm{m}^{2}\right.$ 相当）以上の降灰が堆積している。このうち南九州の鬼 界カルデラ (薩摩硫黄島) で約 7300 年前に発生した噴火 に伴う鬼界アカホヤ (K-Ah) 火山灰と呼ばれる降灰は, 西日本の縄文文化を長期間衰退させたと考えられる ${ }^{3)}$
原子力発電所では，低頻度な自然外部事象も影響評価対 象としており，巨大噴火の降灰も含まれる ${ }^{1), 2)}$ 。

これほど巨大でなくとも，広域的に多量の降灰をもた ら寸噴出物量 $1 \mathrm{~km}^{3}$ 規模の大規模噴火は, 日本列島では 100 年あたり 4, 5 回の頻度で発生してきた。例えば 18 世紀の関東地方は，富士山 1707 年（宝永）噴火之，浅間 山 1783 年（天明）噴火の降灰を被った ${ }^{4)}$ ) 5)。しかし，同 規模の噴火は桜島 1914 年（大正）噴火以来，最近 100 年 間は偶然にも発生せず，現代日本社会は降灰への脆弱性 が顕在化しないまま経済発展を遂げたといえる。一方, 桜島（図2）のように頻繁に噴火する火山の近傍では，小 規模な降灰が日常的に発生している。関東地方では浅間 山の噴火による降灰が近年も繰り返し平野部に到達して (る5)

降灰は火山から離れた地域でも噴火発生から短時間の うちに開始し, 長時間継続する。日本付近の高層大気の 特性上，噴煙は時速約 $100 \mathrm{~km}$ の割合で拡大寸ると考えら れる。また, 富士山宝永噴火や世界各地で近年発生した 噴火では, 数日〜数週間の噴火期間中に, 噴煙・降灰が 半日〜数日間連続する状態と活動が低下する状態を繰り 返している ${ }^{6-8)}$

今後発生し得る多様な降灰を予測・評価するには, 過 去の発生実績を調查するとともに，数值流体解析手法に 基づき規模, 大気条件を異にする降灰を再現する必要が ある。また, 解析結果を活用し噴煙・降灰の発生状況を 図示することにより，災害に対する理解を促進すること

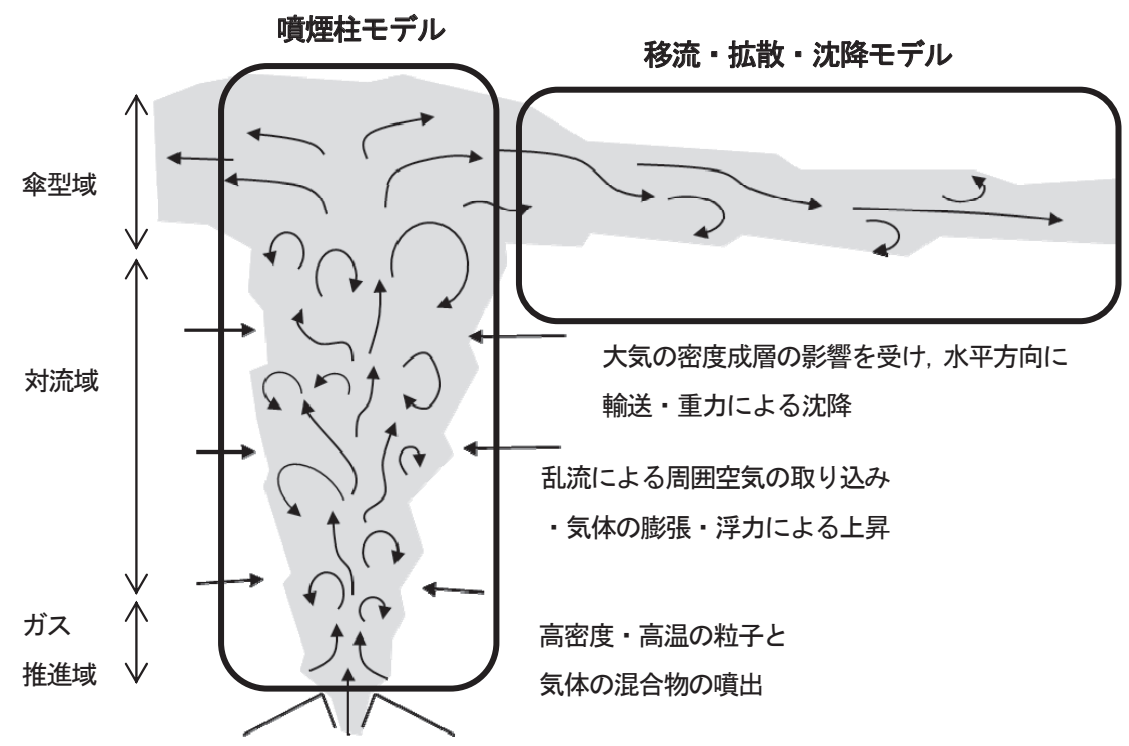

図 1 解析モデルの対象領域と火山灰の輸送過程の概略 
が可能となる。

\section{2 降灰災害と対策の特徵}

降灰発生時には火山灰粒子が浮遊・付着・堆積するこ とにより，同時多発的に多様な影響が発生する ${ }^{9)}$ 。

降灰粒子の大気中の質量濃度は $1 \mathrm{~g} / \mathrm{m}^{3}$ 以上と推定され ており ${ }^{10)}$, 国内の黄砂の観測值や砂漠地帯の粒子量 $\left(0.1 \mathrm{mg} / \mathrm{m}^{3}\right)$ の 1 万倍を超える。このため, 空気を取り 込み燃焼させるガスタービン機器は短時間で影響を受け やすい。航空機ではジェットエンジンが停止する事象が 発生しており ${ }^{11)}$, これを䂆方するための運行停止措置に より国際的な影響が生じている。また，国内では多数の 天然ガス火力発電所が火山の風下側, 寸なわち降灰の発 生可能性が大きい地域に集中的に立地している。発電所 のガスタービン建屋にはフィルタが設置されているが ${ }^{12)}$ 降灰発生時には短時間で交換基準に達すると予想される。 このため, 付着した粒子の自己洗浄機能を有するフィル タの開発など，設計上の対応が急務である。降灰粒子の 機器への付着・侵入等の対策において, 数值流体解析結 果を実験的手法と併用することが考えられる。

降灰が堆積すると屋根は荷重の影響を受ける。また, 二次的な現象として，風による舞い上がりや土石流の発 生が懸念される。さらに，火山灰粒子を湿らせると粒子 に付着した硫化物が溶け硫酸イオンとなるため, 雨天時 に発生する降灰では送配電設備の絶縁への影響が生じる 13)。碍子でのせん絡（フラッシュオーバ）の発生に起因 するものであり, 発生可能性は碍子の型式や設置状況に より大幅に異なる ${ }^{14)}$ 。雨天時の降灰では, 倒木等の影響 も大きい。このように，降灰の現象と影響，対策には， 海塩や着雪・着水災害との共通項が多い。
各影響に共通する対策は人手による除去作業である。 しかし，降灰により道路交通が制約され，人員の確保や 物資の流通が阻害されるため, 各種資源が不足する中で 復旧作業を行う必要がある。このため, 豪雪等の大規模 災害時に顕在化した対応上の諸課題 ${ }^{15)}$ が，降灰において も発生すると予測される。そこで，事業継続計画 (BCP) 等を策定し, 組織・事業所間の役割分担，除去作業の優 先順位や除去後の火山灰処分場を予め定めておく必要が ある。また，直接的な対策をとらない事項については， 代替策や補償制度の整備が必要である。

降灰現象・災害の特性は火山や災害の専門分野ではよ く知られているが，広域的な対策は開始されたばかりで ある。数值流体解析を活用することにより，降灰現象に 対する理解が幅広い分野の専門家に共有され，降灰の影 響評価・対策が推進されリスクが軽減されることが期待 される。

上述の通り, 数值流体解析は降灰災害に関わる評価と 広く関連性を有している。以下では,このうち, 降死の ハザード評価に関する数值流体解析技術に着目し，それ らの現状と課題を具体的に示していく。

\section{3. 火山灰の移流・拡散・沈降}

3 章では, 火山灰の大気中での輸送現象, 特に主要因で ある移流・拡散・沈降過程を取り上げる。その物理現象 を概説した後, 既往の評価モデルの特徵, 代表的な解 析事例および技術課題を整理する。

\section{1 火山灰の輸送現象}

噴火後の降灰性状は, 大気中での火山灰の輸送現象に 依存する。この火山灰の大気中での輸送は，主に移流・

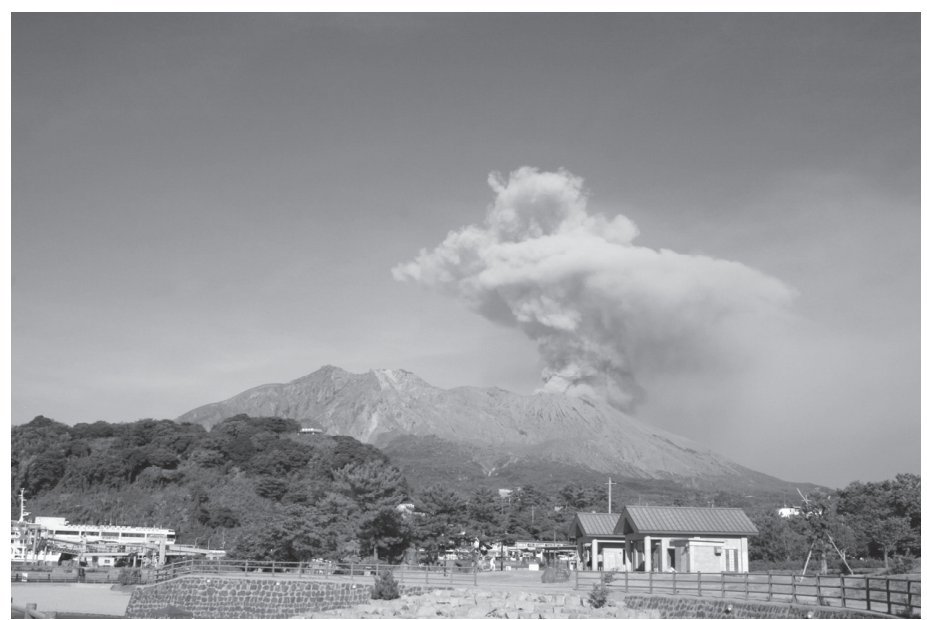

図 2 桜島噴煙の様子（2013/7/21 撮影 $)$ 
拡散・沈降過程からなる。火山灰の沈降は，火山灰粒子 に対する重力と抵抗力との平衡状態下での落下速度（終 端速度）とともに行われる。終端速度は, 粒子直径（直 径分布), 形状 (真球度), 質量等の火山灰粒子の空力特

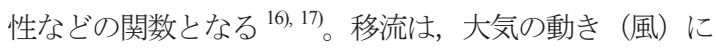
起因寸る水平・鉛直方向移動とともに行われる。風速・ 風向の時空間分布の関数となる。拡散は, 乱流拡散を主 要因とし, その拡散係数は, 風の乱れの強さやスケール, 大気の安定度などの関数となる。加えて, 乾性・湿性沈 着や火山灰粒子同士の凝集にともなう空力特性の変化 ${ }^{18)}$, 火山灰が雨の核となる沈降加速 ${ }^{19)}$ なども輸送過程の無視 しえないパラメータになることに留意されたい。

このように大気の運動と強い関連を有する火山灰の大 気中での輸送過程を議論する上で, 大気場の鉛直構造 ${ }^{20)}$ にも留意を要する。例えば，火山灰の移流・拡散・沈降 挙動は, 噴煙柱の高さが成層圈に及ぶものと, 対流圈内 に収まるものとで異なる性状を呈する ${ }^{17,21,22) 。 こ れ ら は ~}$ それぞれ，噴煙柱高さによる噴火現象の区分として表現 される”strong plume”と”weak plume”に対応する。 strong plumeでは, 火山灰は対流圈と成層圈との境界 (圈界面) まで上昇した後，沈降によるわずかな鉛直移動とともに 主に水平方向一移流寸る。一方, weak plumeでは，火山 灰は対流圈内に滞在する。そして, 水平だけでなく鉛直 方向一の移流・拡散も見せる。その運動形態は, 風速・ 風向の鉛直勾配 ${ }^{23)}$, 24), 火山周辺の地形に起因寸る局地風 16,25), 噴煙柱自体の曲がり 2),6)等の影響を受けて, 複雑な ものとなることが多い。

\section{2 既往の評価モデル}

数值流体解析技術を活用したモデルでは，大気中での 火山灰の運動を支配する偏微分方程式群（Advection-

Diffusion-Sedimentation, ADS 方程式）を基礎方程式とす る。それらに離散化を施し, 境界条件として与える気象 場や噴煙柱の情報に対して, 大気中の火山粒子 (火山粒 子群もしくは濃度）の運動および地面への沈降挙動に関 する解が数值計算により導かれる。

これまでに提案されているモデルを俯瞰すると ${ }^{4}$, 火山 灰の運動の微分表現に準じてラグラジアンタイプとオイ ラータイプとに大別される。前者では, 火山灰粒子（一 般的には粒子群）の運動を追跡する。一方，後者では火 山灰の空気中に占める割合 (濃度) に対する偏微分方程 式を固定座標系において解く。

両タイプに共通して, モデルの予測挙動は, (1) 移流項,

(2) (乱流) 拡散項, (3) 沈降速度, (4) ソース・シンク項 に依存する。ここで, (1) 移流項については, 鉛直成分を
無視し，水平方向への移流のみをしばしば考慮すること を強調したい。この近似は, 計算負荷の低減を図るため に施される。特に, ソース・シンク項への準定常近似を 同時に付加することで, ADS 方程式に対して半理論解を 得られること（経験定数を含む解析解が理論的に導かれ る) が大きなメリットとなる。(2)乱流拡散項については, 渦拡散係数によりモデル化される。渦拡散係数の表現方 法は, 主に, 数值気象モデルのものに相当するが，移流 項と同様に半理論解を得るための簡易化が施されること もある。(3)沈降速度については，火山灰粒子の空気抵抗 の表現方法に関していくつかのモデルが提案されている。 レイノルズ数依存性, 非球形状効果の取り込みに工夫が ある。(4)ソース・シンク項は, 乾性・湿性沈着の効果の 取り込みの有無に関するもので, 乾性沈着について, 沈 着速度などによるモデル化が施される。

\section{3 応用・解析事例}

降灰シミュレーションの応用先の一つとして, 大気中 の火山灰濃度評価を通じた航空機運用に対寸る支援情報

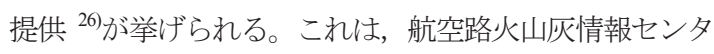
一 (Volcanic Ash Advisory Center, VAAC) での利用に代表 される。ここでは, 「予報」として運用が行われることか

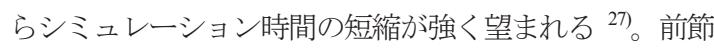
に述べた半理論解の導入は, この要求を背景としたもの である。また, シミュレーションだけでなく衛星情報と いった観測データの連携にも力点がおかれている。さら に関連機関との情報共有の効率化に際して, 情報フォー マットの高度化等も進められている。

もう一つの応用先として, 2 章に述べたハザード評価が 挙げられる。ここでは， Folch and Sulpizio（2010） ${ }^{18)}$ によ る Vesuvio 火山噴火時に対する評価事例に見られるよう に, 比較的計算負荷の大きい非定常三次元モデル (FALL3D モデル) が用いられている。

近年では, シミュレーションを援用し, 噴火事象の構 造解明を進める事例も報告されている。これは, 気象場 の再解析データ（ERA40， ERA-Interim，JRA25 等）の整 備が進み, 過去の気象場を境界条件として与えた火山灰 輸送計算の実施が容易となってきたことに起因する。 VOL-CALPUFFによる2001年Etna 山噴火の再現計算 ${ }^{16)}$, $\mathrm{PUFF} / \mathrm{HYSPRIT}$ による 1992 年 8 月の Spurr 山噴火の再現 計算 ${ }^{28)}, \mathrm{PUFF} / \mathrm{HAZMAP}$ で 1991 年の Pinatubo 火山の噴 火再現計算 ${ }^{29)}$ 等などの報告がある。

\section{4 技術課題}

ここまでに述べたとおり，降灰性状を評価するモデル の開発・活用は, 精力的に進められている。3.3 節に述べ 
たとおり，火山灰の移流・拡散・沈降の評価モデルは， 近年，ハザード評価事例も蓄積している。

しかし，モデルの精度評価を目的としたベンチマーク テストは, これらモデルが未だ開発途上にあることを示 唆している。例えば, Scollo et al. $(2008)^{21)}$ は3つのモデ ル（FALL3D, HAZMAP, TEPHRA）を対象に，2002-2003 年および 1990 年の Etna 山噴火 (weak plume と strong plume との 2 つの噴火シナリオに相当)の再現を課題とし たベンチマークテストを行っている。そして，噴火の境 界条件 (噴煙柱高さ, 噴出質量, 粒子直径等) が解析結 果に強く影響すること，これらパラメータの設定方法を それに関連する物理モデル（噴煙柱モデル）とともに改 良していくことが重要と結論を提示している。また,

Webley et al. (2009) ${ }^{28)}$ は2つのモデル(PUFF と HYSPLIT) を対象に, 1992 年の Spurr 山噴火の再現を課題としたべ ンチマークテストを行い, 両モデルの結果が有意な差を 呈すること, その原因解明には更なる検討を要すること を指摘している。一方, Witham et al. (2007) ${ }^{30}$ は, VAAC で使われている4つのモデル(NAME, MEDIA, CANERM, HYSPLIT）を対象に，2004 年の Grimsvötn 火山噴火の再 現を課題としたベンチマークテストを行っている。ここ では，モデル間には物理過程の表現方法や境界条件の与 え方に差異があるにもかかわらず，火山灰濃度の分布は 類似の予測結果となった。この一致には, 明確な解釈が 与えられていない。また, 拡散過程のモデル化について は，勾配拡散型のモデルにおいて，普遍的な拡散係数の 設定が難しいという指摘がなされている ${ }^{17}$ 。LES の活用 は，その解決になりえるものであるが，混相流（火山灰 と大気）での SGS モデルの取り扱いは新たなる課題を産 みえる ${ }^{31)}$ 。

ここまでに述べた物理モデルの高度化だけでなく, 適 切な境界条件の確立も, シミュレーションの精度向上に つながるものである。降灰シミュレーションの境界条件 として, 噴火条件に関するものだけでなく, 気象条件に 関するものもある。Byrne et al.(2007) ${ }^{24}$ は，CerroNegro 山 の噴火再現を行い, 通常の計算と同様に, 再解析值の結 果を気象場の境界条件とした場合は, 堆積量の分布に有 意なずれが生じること，このずれは数值気象モデル (MM5) とカップリングしたモデルで水平方向の空間解 像度を $9 \mathrm{~km}$ にまであげることで解消寸ることを報告して いる。Turner and Hurest (2001） ${ }^{32)}$ の検討では，更に高い 解像度 (空間解像度 $2.5 \mathrm{~km}$ 程度) を求める結果が得られ ているが，これは，山岳波が現象を支配しているためと 考えられる。実際, Fero et al. (2009) ${ }^{29}$ による PUFF/
HAZMAP の解析では，再解析值（ERA 40）を境界条件と して, 1991 年 Pinatubo 山噴火の再現計算を行っているが, ERA40 が持つ風向の予測誤差が，実測と異なる降灰分布 の再現を引き起こす結果となっている。Daniele et al. (2009) ${ }^{33)}$ による PUFF を用いた 1998 年 Vesuvio 山噴火の 再現計算でも風の場が噴煙柱と堆積分布に強く影響する ことを示しており, その高度化への要望を明記している。 また, Hattori et al. ${ }^{34)}$ は, 数值気象モデル wrf をコアとする, 電中研気象予測・解析システム NuWFAS と FALL3D とを 連係させた，2011 年 1 月の新燃岳噴火を対象とした数值 実験において, 気象計算のパラメータが降灰シミュレー ション結果に与える結果を体系的に示しており, 特に, weak plume における火口近傍での降灰予測が精緻な気象 再現を求めることを明らかにしている。

\section{4. 噴煙柱}

4 章では, 噴煙柱の運動を取り上げる。その物理現象を 概説した後, 既往の評価モデルの特徽, 代表的な解析事 例および技術課題を整理する。

\section{1 噴煙柱の運動}

爆発的な噴火では，高温状態で破砕したマグマの破片 である火砕物と水蒸気等の火山ガスの混合物が噴霧流と して火口から勢い良く噴出する。更に, 噴出した混合物 は大気と混合しながら上昇し，噴煙柱を形成する。この 運動は, 浮力と火口での運動量を原動力とする点で, 流 れの形態として強制プルームに分類されるものである ${ }^{35}$ ただし，空気等を対象とした一般的な強制プルームとは 異なり，上昇の過程において，混合物の見かけ上の物性 は温度や圧力だけでなく火砕物の混合比によっても大き く変化する。噴出時の運動量や混合物の密度・温度等に 依存して, 十分な浮力が得られない場合の噴煙は, 火砕 流として地表斜面を駆け下ることとなる。また，十分な 浮力が得られる場合にも, 混合物が連続的に放出される 場合と, 瞬時的に放出される場合がある。前者は強制プ ルーム，後者はサーマルと呼ばれる単発的な上昇流であ り，両者は異なる性質を示す。更に，火山の規模によっ て噴煙は高度数百 $\mathrm{m}$ 程度から数十 $\mathrm{km}$ に達寸るものもあ り，大気密度の鉛直方向の変化も強く影響寸る。

一例として, 強制プルームの特性を有する火山噴火（プ リニー式噴火）を取り上げ，噴煙柱の構造の概略を述べ る。図 1 に示寸とおり, 噴煙柱は, 下から, ガス推進域, 対流域, 傘型域という3 つの領域に分けられる ${ }^{35,36) 。 ~}$ ガス推進域：火砕物と火山ガスの混合物に対して, 火

口からの噴出速度は数 $100 \mathrm{~m} / \mathrm{s}$, 温度は $1000 \mathrm{~K}$ 程度, 混 
合物の密度は大気の密度の数倍〜十倍程度である ${ }^{37), 38)}$ よって, 混合物の上昇速度は, 大気に放出された直後 から重力の影響により急速に減少する。それと同時に, 噴煙は乱流の渦運動により周囲の空気を取り込む。

対流域：取り込まれた空気は火砕物からの熱により瞬 時に温められ, 膨張し, 密度は低下寸る。空気を取り 込んだ混合物の密度が大気の密度より小さくなると, 浮力の効果により混合物の上昇速度は増加する。

众型域：周囲の大気密度は高度とともに減少するため, 混合物の密度がこれと等しくなると浮力はゼロとなり, 次第に鉛直上向きの運動量を失い, 水平方向に広がる。

\section{2 既往の評価モデル}

噴煙柱を形成する爆発的な噴火では，火砕物，火山ガ ス，および空気が混合した状態で運動する。ここで，火 砕物のスケールは数十 $\mu \mathrm{m}$ 数 $\mathrm{m}$ と大きな幅があり, ス ケールに応じてその運動は変化する。しかし，粒径分布 のフィールドデータのレビューによると，火砕物の $90 \%$

(重量比) 以上が $5 \mathrm{~mm}$ 径以下， $60 \%$ 以上が $1 \mathrm{~mm}$ 以下で あり ${ }^{39)}$ ，噴煙柱の基礎的な物理過程は数 $\mathrm{mm}$ 以下の小さ な火砕物を対象にすることで説明される ${ }^{35)}$ 。こような 前提の下，既往の検討では，小さな火砕物と気体の混合 物を近似的にある単一の状態方程式に従うとする一流体

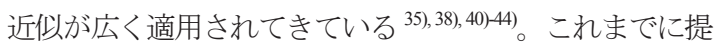
案されている主要なモデルの概略は, 須藤・服部 (2011) 4)を参照されたい。以下に，代表的なモデルを例に，具体 的な内容を述べる。

噴煙柱の運動は，実際には非定常・三次元であるが， 単純な保存則と一流体として表現される混合物の状態方 程式を基にした定常・一次元の噴煙柱モデルが初期の検 討において構築され 35,38$), 40)$, 近年においても高度化が図

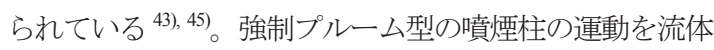
力学的, 熱力学的に統一的に定式化したものは, Woods (1998） ${ }^{35)}$ の一次元噴煙柱モデルである。本モデルにお いて, 定常・一次元の質量, 運動量, エネルギーが基礎 方程式として用いられる。このモデルは，上述の通り粒 径の大きな火砕物の体積分率が小さく, 噴煙柱内部で強 い圧力が生じない範囲において適用可能である。実際に は火口において高い圧力で噴出することも考えられるが, 通常は急速に大気圧まで減圧されるものとして扱われる。 ただし，この点について，高圧での噴出はガス推進域か ら対流域への遷移を遅らせ，噴煙柱の崩壊を周期的に励 起するとの指摘もある ${ }^{46)}$ 。また, 周囲の大気の引き込み （エントレインメント）は，噴煙柱の特性を決定づける 重要な要素の一つであるが, この効果は経験的なエント
レインメント係数 ${ }^{47)}$ として基礎方程式に組み込まれてい る。強制プルームの性質を有する噴煙柱に対して通常 0.1 といら值が用いられるが, 近年では, ガス推進域と対流 域での現象の違いに応じてこの值を変化させることによ り精度の向上が図られるとの報告もある ${ }^{43)}$ 。このような 一次元噴煙柱モデルによる解析結果は, 2.1 節に述べたガ 又推進域, 対流域, 金型域の特徴を良く捉えることが確 認されている ${ }^{35)}$ 。

一方，軸対称性や定常性を前提とした一次元モデルの 適用が困難な現象として，強い横風を受ける噴煙柱，噴 煙柱の部分的な崩壊により発生する火砕流, 噴煙柱から 火砕流への遷移等の本質的に時間に依存するもの等が挙 げられる。横風を受ける噴煙柱の評価に対しては，二次 元の座標系を基にした定常噴煙柱モデル等 44), 48)が提案さ

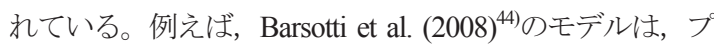
ルームが曲線座標に沿った円形断面を有するものと仮定 される。この時, エントレインメントは, 強制プルーム の乱れによるものと横風によるものの 2 つが想定され, 経験的な定数を用いて表現される。ただし，横風による 二次的な渦の効果は直接考慮されていない。また，火砕 流への遷移等には適用できない。より複雑な非軸対称の 噴煙柱や時間に依存する問題に対しては, 非定常・三次元 の噴煙柱モデルが提案されている。これらのモデルは, エントレインメントを経験的な係数で表現するのではな く，解析において乱れの効果として直接再現する点にお いて, 上述の一次元あるいは二次元の定常モデルとは大 きく異なるものである。非定常現象に対しては, 非定常・ 二次元モデルによる評価が多く見られるが 46), 49)-53), 近年 の計算機性能の飛躍的な向上に伴い，三次元のモデルも 現象解明等に利用されつつある 41), 42), 54)。また, 非定常・ 三次元モデルの中でも, 前述の一流体近似を基本にし, 気体と噴煙の速度差を無視したものと ${ }^{41), 42)}$, この速度差 を考慮したもの (多流体近似) ${ }^{53)}$ とがある。この速度差 を考慮したものには，多流体近似以外に，粒子一つ一つ の運動を追跡するラグランジュ的アプローチもあるが， 噴煙柱評価への適用例は限定的である ${ }^{55)}$

\section{3 解析事例}

一次元噴煙柱モデルは, 解析パラメータの影響等につ

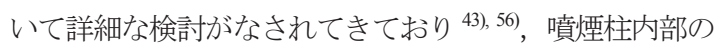
運動のみならず，噴煙の規模等の野外観測結果を基にし た火口条件の推定等にも有用なツールである ${ }^{36), 43) 。 こ の ~}$ モデルを実際の火山噴火に適用した例としては, St. Helens 山や有珠山の噴火時に発生した顕著な噴煙に適用

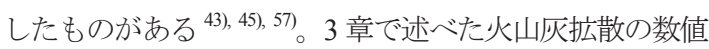


シミュレーションのための発生源の条件設定等には，噴

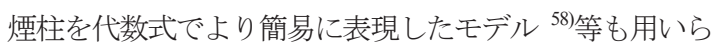
れる ${ }^{21,59)}$ 。

一方, 非定常・多次元噴煙柱モデルは, 一次元噴煙柱 モデルでは不可能であった噴煙柱の崩壊 ${ }^{49}$, 53)，噴煙柱に おける乱流の効果 ${ }^{60)}$, 噴煙柱の安定性に対寸る火口での

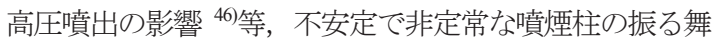
い等に関する現象解明に主に利用されている。同モデル を実際の火山噴火に適用した例として, Vesuvio 山 ${ }^{54)}$, Etna 山 ${ }^{16)}$, Pinatubo 山 ${ }^{61)}$ 等に対するものが散見されるが，事 例は少ない。一次元噴煙柱モデルに比べて, 歴史が浅く 開発途上にあるモデルが多いこと，実現象を再現するた めの精緻な噴出条件を設定するには，詳しい調査，観測 等が不可欠であること等がその理由として考えられる。 ただし, 非定常・多次元噴煙柱モデルによる現象の理解 は，一次元モデル等のより簡易なモデルの高度化にも繋 がるものと考えられる ${ }^{55)}$

\section{4 技術課題}

前節に示したとおり, 初期に確立された一次元噴煙柱 モデルは，噴煙柱内部の運動や火口条件の推定，あるい は広域一の噴煙拡散・降灰の数值解析のための発生源の 条件設定等に用いられている。そして, モデル定数の最 適化 ${ }^{43}$ や水蒸気影響の考慮 ${ }^{45}$ )等の高度化もなされており， 軸対象性等の制約の下でパラメータ感度を含めた詳細な 知見が集積されつつある。

他方, 多次元・非定常噴煙柱モデルは, 一次元モデル では適用が難しい強い横風を受ける噴煙柱や，噴煙柱の 崩壊により発生する火砕流の評価, 更に噴煙柱内部の乱 れの効果等の現象解明に対して, 近年, 利用されるよう になってきている。ただし，一次元モデルに比べて，現 時点での検討事例は極めて少なく, 利用されているモデ ル式の適用性には検討の余地がある。例えば, Neri et al. $(2007)^{54)}$ が Vesuvio 山の噴煙柱に適用した多流体モデル は，既往の知見を基に気体相・粒子相の忍力テンソルや 気体-粒子間・粒子-粒子間の抗力係数等を，それぞれの素 過程の要素モデルにより表現しているが, その適用性に ついては十分明らかにされていない。 Suto et al. (2013) は, 解析格子より小さいスケール (sub-grid scale, SGS) の 渦のみをモデル化するラージエディシミュレーション

（LES）において，SGS の渦に比較的多くの運動エネル ギーが分布する実規模の噴煙柱を対象とする場合には, 要素モデルの一つである SGS 乱流モデルの種類が噴煙柱 形状等に影響を及ぼす可能性を指摘している（図 3)。

更に，現象を精緻に再現できる利点により，実現象と

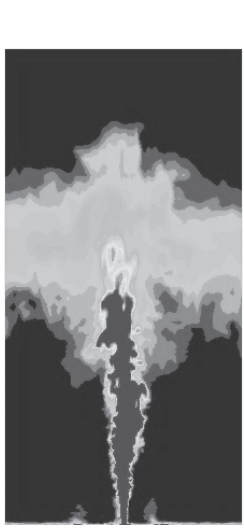

(a) Smagorinsky model

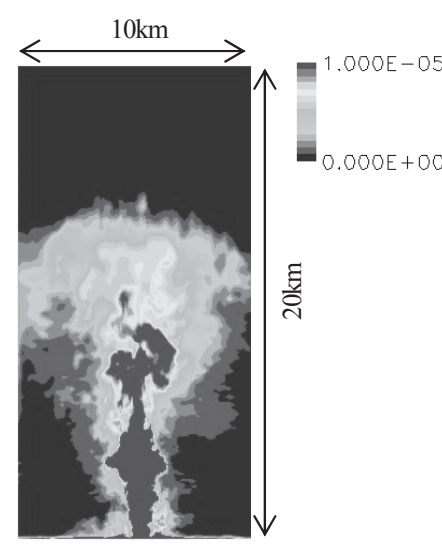

(b) Yuu model
図 3 噴煙柱の LES におけるSGS モデルの影響 (瞬時の粒子体積分率分布) ${ }^{60)}$

して特徵的に見られる灰神楽 (火砕流の上面から生成さ れる噴煙の上昇流）やウインドシアの影響を受ける噴煙 柱等に対する噴煙輸送現象の解明 ${ }^{62)}$, 噴煙柱の形成と 共に生じる水の相変化等のミクロスケールで生じるもの の影響評価等に対する可能性も有しているが (3), 64), これ らの現象の理解には，モデルの有する不確実性を踏まえ た更なる検討が必要である。

\section{5。まとめ}

本報では, 重要構造物に対する降灰のハザード評価の 視点から, 様々な降灰災害とその数值流体解析との関 わりについて述べると共に, 火山灰の輸送に関わる数 值流体解析技術の現状と今後取組みが望まれる課題を整 理した。

なお，ここでは，火山灰輸送の解析技術の動向に注 目して記述したが，その技術課題への取組みにおいては, 異なる分野の知見や技術の展開がブレークスルーに繋が る可能性もある。例えば, 火山灰の挙動再現の向上, 精 緻な現象の理解, 大気の鉛直構造再現の向上の観点から は, 火山灰以外の他の物質の大気中の輸送過程 ${ }^{65-(68)}$ に対 する知見の展開, 現象を適切に模擬した模型実験 $\left.{ }^{69,}, 70\right)$ の 援用, 力学的ダウンスケーリングを活用した最新の気象 再解析值の利用等も有用之考えられる。今後は, これら の手法の過去の噴火等への適用を進め, 精度検証事例を 蓄積していくことも大事だろう。

\section{参考文献}

1) IAEA (International Atomic Energy Agency), "Volcanic 
hazards in site evaluation for nuclear installations", IAEA Safety Standards, SSG-21, (2012)

2) 日本電気協会，「原子力発電所火山影響評価技術指針 JEAG4625-2009」, (2009)

3) 町田洋, 新井房夫 (編), 「新編 火山灰アトラス」, 東京大学出版会, (2003)

4）須藤仁，服部康男，「数值流体解析を用いた降下火山 灰のハザード評価技術に関する調查」, 電力中央研究 所報告, N10028, (2011)

5) 気象庁 (編)「日本活火山総覧（第4 版)」,(2013)

6) 小山真人「富士山噴火とハザードマップ」，古今書 院, (2009)

7) Gudmundsson, M. T., Thordarson, T., Ho skuldsson, A', Larsen, G., Bjo ̈nsson, H., Prata, F. J., Oddsson, B., Magnú sson, E., Ho "gnadóttir, T., Petersen, G. N., Hayward, C. L., Stevenson, J. A., and Jo' nsdo' ttir, I., “Ash generation and distribution from the April-May 2010 eruption of Eyjafjallajo kull, Iceland", Sci. Rep. 2, 572; DOI:10.1038/ srep00572, (2012)

8) Mastin, L.G., Guffanti, M., Servranckx, R., Webley, P., Barsott, S., Dean, K., Durant, A., Ewert, J. W., Neri, A., Rose, W. I., Schneider, D., Siebert, L., Stunder, B., Swanson, G., Tupper, A., Volentik, A., Waythomas, C. F., "A multidisciplinary effort to assign realistic source parameters to models of volcanic ash-cloud transport and dispersion during eruptions", J. Volcanol. Geotherm. Res., Vol. 186, pp. 10-21, (2009)

9) 土志田潔, 「降下火山灰の体系的リスク評価に向け て -留意点と課題-」, 電力中央研究所報告, N09031 (2010)

10) Kim, J., Dunn, M. G., Baran, A. J., Wade, D. P. and Tremba, E. L., "Deposition of volcanic materials in the hot sections of two gas turbine engines", J. Engineering for Gas Turbines and Power, Vol. 115, pp. 641-651, (1993).

11) Guffanti, M., Casadevall, T. J., and Budding, K., "Encounters of aircraft with volcanic ash clouds: A compilation of known incidents", U. S. Geological Survey Data Series 545, (2010)

12) 吉竹茂,「ガスタービン吸気フィルタ技術」，日本ガ スタービン学会誌, Vol. 37,pp. 7-12, (2009)

13) Wardman, J. B., Wilson, T. M., Bodger, P. S., Cole, J. W., Johnston D. M., "Investigating the electrical conductivity of volcanic ash and its effect on HV power systems", Physics and Chemistry of the Earth, Vol. 45-46, pp. 28-145,
(2012)

14）川畑秋馬, 入佐俊幸, 上妻生朗,「火山灰污損がいし の漏孔電流特性」，電気学論文集 B, 115, pp. 956-963, (2003)

15）廣瀬文子, 佐相邦英，三浦大助，「自然災害復旧時に おけるヒューマンファクター上の課題」, 電力中央研 究所報告, Y08037, (2009)

16) Barsotti, S., Neri, A., "The VOL-CALPUFF model for atmospheric ash dispersal: 2. Application of the weak Mount Etna plume of July 2001”, J Geophysical Res, Vol. 113, B03209, (2008)

17) Bonadonna, C., Philips, J. C., Houghton, B. F, "Modeling tephra sedimentation from a Ruapehu weak plume eruption", J Geophysical Res, Vol. 110, B08209, (2005)

18) Folch, A., Sulpizio R., "Evaluating long-range volcanic ash harzard using supercomputing facilities: application to Somma-Vesuvius (Italy), and consequences for civil aviation over the central Mediterranean area", Bull Volcanol: DOI 10.1007/s00445-010-0386-3, (2010)

19) Rose, W. I. and Durant, A. J., "El Chichon volcano, April 4, 1982: volcanic cloud history and fire ash fallout", Nat Hazards, Vol. 51, pp. 363-374, (2009)

20) 小倉義光,「一般気象学 第 2 版」, 東京大学出版会, (1999)

21) Scollo, S., Folch, A., Costa A, "A parametric and comparative study of different tephra fallout models", J Volcanology and Geothermal Res, 176, pp.199-211, (2008)

22) Lim, L. L., Sweatman, Wl., McKibbin, R., Connor, C. B., "Tephra fallout models; the effect of different source shapes on isomass maps", Math Geosci, Vol. 40, pp. 147-157, (2008)

23) Walcek, C. J., "Effects of wind shear on pollution dispersion", Atmospheric Environment, Vol. 36, pp. 511-517, (2002)

24) Byrne, M. A., Laing, A. G., Connor, C., "Predicting tephra dispersion with a mesoscale atmospheric modeling and a particle fall model: application to Cerro Negro volcano", J Applied Meteorol Climatol, Vol. 46, pp. 121-135, (2007)

25) Costa, A., Macedonio, G., Folch, A., "A three-dimensional Eulerian model for transport and deposition of volcanic ashes", Earth and Planetary Sci Lett, Vol. 241, pp. 634-647, (2006)

26) Prata, A. J. and Tupper, A., "Aviation hazards from 
volcanoes: the state of the science", Nat Hazards, Vol. 51, pp. 239-244, (2009)

27) Albersheim, S., Guffanti, M., "The United States national volcanic ash operations plan for aviation", Nat hazards, Vol. 51, pp. 275-285, (2009)

28) Webley, P. W. , Stunder, B. J. B., Dean, K. G., "Preliminary sensitivity study of eruption source parameters for operational volcanic ash clouod transport and dispersion models - A case study of the August 1992 eruption of the Crater Peak vent, Mount Spurr, Alaska”, J Volcanology and Geothermal Research, Vol. 186, pp. 108-119, (2009a)

29) Fero, J., Carey, S. N., Merrill, J. T., "Simulating the dispersal of tephra from the 1991 Pinatubo eruption: implications for the formation of widespread ash layers", J Volcanology and Geothermal Res, Vol. 186, pp. 120-131, (2009)

30) Witham, C. S., Hort, M. C., Potts, R., Servranckx, R., Husson, P., Bonnardot, F., "Comparison of VAAC atmospheric dispersion models using the 1 November 2004 Grimsvötn eruption", Meteorological Applications, Vol. 14, pp. 27-38, (2007)

31) Weil, J. C., Sullivan, P. P., Moeng, C-H, "The use of large-eddy simulations in Lagrangian particle dispersion models", J Atmospheric Sciences, Vol. 61, pp. 2877-288, (2004)

32) Turner, R., Hurst, T., "Factors influencing volcanic ash dispersal from the 1995 and 1996 eruptions of Mount Ruapehu, New Zealand", J Applied Meteorology, Vol. 40, pp. 56-69, (2001)

33) Daniele, P., Lirer, L., Petrosino, P., Spinelli, N., Peterson, R., "Applications of the PUFF model to forecasts of volcanic clouds dispersal from Etna and Vesuvio", Computers and Geosciences, Vol. 35, pp. 1035-1049, (2009)

34) Hattori, Y., Suto, H., Go, Y., Toshida, K., Hirakuchi, H., Ishihara, S., "Sensitivity study of numerical weather-model parameters for quantitatively estimating ash concentration in the atmospheric surface layer with a computational ash dispersion model, FALL3D”, Proc IAVCEI 2013, 1227-1, (2013)

35) Woods, A. W., "The fluid dynamics and thermodynamics of eruption columns", Bull Volcanol, Vol. 50, pp. 169-193, (1988)

36) 小屋口岡博，「火山現象のモデリング」，東京大学出
版会, (2008)

37) Lipman, P. W. and Mullineaux, D. R., "The 1980 eruptions of Mount St. Helens, Washington", US Geological Survey Professional Paper, 1250, 40, (1981)

38) Sparks, R. S. J., "The dimensions and dynamics of volcanic eruption clums", Bull Volcanol, Vol. 48, pp. 3-15, (1986)

39) Sparks, R. S. J. and Wilson, L., "A model for the formation of ignimbrite by the gravitational column collapse", J Geol Soc London, Vol. 132, pp. 441-451, (1976)

40) Wilson, L., "Explosive volcanic eruptions-III. Plinian eruption columns", J R Astrom Soc, Vol. 45, pp. 543-556, (1976)

41) Suzuki, Y. J., Koyaguchi, T., Ogawa, M. and Hachisu, I., "A numerical study of turbulent mixing in eruption clouds using a three-dimensional fluid dynamics model", J Geophys Res, Vol. 110, B08201, (2005)

42) Suzuki, Y. J. and Koyaguchi, T., "A three-dimensional numerical simulation of spreading umbrella clouds", J Geophys Res, Vol. 114, B03209, (2009)

43) Carazzo, G., Kaminski, E. and Tait, S., "On the dynamics of volcanic columns: A comparison of field data with a new model of negatively buoyant jets", J Volcanol Geotherm Res, Vol. 178, pp. 94-103, (2008)

44) Barsotti, S., Neri, A. and Scire, J. S., "The VOL-CALPUFF model for atmospheric ash dispersal: 1 . Approach and physical formation", J Goephys Res, Vol. 113, B03208, (2008)

45) Mastin, L. G., "A user-friendly one-dimensional model for wet volcanic plume", Geochemistry Geophysics Geosystems, 8-3, Q03014, (2007)

46) Ogden, D. E., Glatzmaier, G. A. and Wohletz, K. H., "Effects of vent overpressure on buoyant eruption columns: Implications for plume stability", Earth and Planetary Science Letters, Vol. 268, pp. 283-292, (2008)

47) Morton, B. R., Taylor, G. I. and Turner, J. S., “Turbulent gravitational convection from maintained and instantaneous source", Proc R Soc Lond, Vol. 234, pp. 1-23, (1956)

48) Devenish, B. J., "Using simple plume models to refine the source mass flux of volcanic eruptions according to atomospheric conditions", J Volcanol Geotherm Res, Vol. 256, pp. 118-127, (2013)

49) Valentine, G. A. and Wohletz, K. H., "Numerical models of 
Plinian eruption colmns and pyroclastic flows", J Geophys Res, Vol. 94, pp. 1867-1887, (1989)

50) Valentine, G. A., Wohletz, K. H. and Kieffer, S. W., "Sources of unsteady column dynamics in pyroclastic flow eruptions", J Geophys Res, Vol. 96, pp.21877-21892, (1991)

51) Neri, A. and Dobran, F., "Influence of eruption parameters on the thermofluid dynamics of collapsing volcanic columns", J Geophys Res, Vol. 99, pp. 11833-11857, (1994)

52) Neri, A., Muro, A. D. and Rosi, M., "Mass partition during collapsing and transitional colmns by using numerical simulations", J Volcanol Geotherm Res, Vol. 115, pp. 1-18, (2002)

53) Neri, A., Ongaro, T. E., Macedonio, G. and Gidaspow, D., "Multiparticle simulation of collapsing volcanic columns and pyroclastic flow", J Geophys Res, Vol. 108, ECV4-1 ECV4-24, (2003)

54) Neri, A., Ongaro, T. E., Menconi, G., Vitturi, M. D., Cavazzoni, C., Erbacci, G. and Baxter, P. J., "4D simulation of explosive eruption dynamics at Vesvius", Geophys Res Lett, Vol. 34, L04309, (2007)

55) Suzuki, Y. and Koyaguchi, T., "3-D numerical simulations of eruption clouds: Efficiency of turbulent mixing caused by environmental wind", JpGU 2013 meeting, SVC50-05, (2013)

56) Ishimine, Y., "Senditivity of the dynamics of volcanic eruption columns to their shape", Bull Volcanol, Vol. 68, pp. 516-537, (2006)

57) 小野忍, 大島弘光，「1977 年有珠山噴火で生じた噴 煙柱の解析」, 北海道大学地球物理学研究報告, (2007)

58) Suzuki, T., "A theoretical model for dispersion of tephra", in: Shimozuru, D., Yokoyama, I. (Eds.), Arc Volcanism: Physics and Tectonics. Terra Scientific Publishing Company (TERRAPUB), Tokyo, (1983)

59）富士山火山防災協議会，「富士山ハザードマップ検討 委員会報告書」,(2004)

60) Suto, H., Hattori, Y. and Toshida, K., "Effects of subgrid-scale turbulent models on spatial structure in large-eddy simulation of a volcanic plume", ICMF2013, (2013)

61) Koyaguchi, T., Ochiai, K. and Suzuki, Y., "The effect of intensity of turbulence in umbrella cloud on tephra dispersion during explosive volcanic eruptions:
Experimental and numerical approaches", J Volcanol Geotherm Res, Vol. 186, pp. 68-78, (2009)

62) Herzog, M. and Graf, H-F, "Applying the three dimensional model ATHAM to volcanic plumes: Dynamic of large co-ignimbrite eruptions and associated injection heights for volcanic gases", Geophysical Research Letters, Vol. 37, L19807, (2010)

63) Durant, A. J. and Rose, W. I., "Sedimentological constraints on hydrometeor- enhanced particle deposition: 1992 Eruptions of Crater Peak, Alaska”, J Volcanol Geotherm Res, Vol. 186, pp. 40-59, (2009)

64) Durant, A. J., Rose, W. I., Sarna-Wojcicki, A. M., Carey, S. and Volentik, A. C. M., "Hydrometeor-enhanced tephra sedimentation: Constraints from the 18 May 1980 eruption of Mount St. Helens”, J Geophys Res, Vol. 114, B03204, (2009)

65）佐田幸一，佐藤歩，市川陽一，「低煙突からの排ガス 拡散予測・数值モデルの開発」, 電力中央研究所報告, V08056, (2008)

66) 道岡武信, 佐藤歩, 「市街地内のガス拡散を対象とし た数值シミュレーション一風洞実験值との比較によ る適用性評価一」, 電力中央研究所報告, V08030, (2008)

67) 須藤仁, 服部康男, 平口博丸, 木原直人,「レイノル ズ平均乱流モデルに基づく風況・海塩粒子輸送解析 一期間累積飛来海塩量の空間分布の推定一」, 土木学 会論文集 B2（海岸工学），66-1,pp.1161-1165, (2010)

68) 木原直人, 平口博丸，高橋章，藤田慎一，「時間変化 する気象条件を考慮できる大気中の海塩粒子濃度予 測手法の開発」，電力中央研究所報告, N08021, (2008)

69) 服部康男, 須藤仁, 平口博丸, 杉本聡一郎, 田中伸和, 「風洞実験による大気接地層の強風変動特性の把 握」，電力中央研究所報告, N08014, (2009)

70) Hattori, Y., Moeng, C-H, Suto, H., Tanaka, N., Hirakuchi, H., "Wind-tunnel experiment on logarithmic-layer turbulence under the influence of overlying detached eddies", Boundary-Layer Meteorology, Vol. 134, pp. 269-283, (2010) 